\title{
Y chromosome in Turner syndrome: review of the literature
}

\author{
Cromossomo Y na síndrome de Turner: revisão da literatura
}

\author{
Rose Mary Rocco de Oliveira', leda Therezinha do Nascimento Verreschi", Monica Vannucci Nunes Lipay"I, \\ Lilian Piñero Eça', Alexis Dourado Guedes ${ }^{\mathrm{IV}}$, Bianca Bianco ${ }^{\mathrm{v}}$
}

Division of Endocrinology, Department of Medicine, Universidade Federal de São Paulo (Unifesp); and Postgraduate Course on Cell and Molecular Biology, Centro de Extensão Universitária (CEU), São Paulo, Brazil

\section{KEY WORDS:}

Turner syndrome.

Chromosomes, human, Y.

Sex cord-gonadal stromal tumors.

Genes, sry.

Mosaicism.

PALAVRAS-CHAVE:

Síndrome de Turner.

Cromossomos humanos $\mathrm{Y}$.

Tumores do estroma gonadal e dos cordões sexuais.

Genes sry.

Mosaicismo.

\begin{abstract}
Turner syndrome (TS) is one of the most common types of aneuploidy among humans, and is present in 1:2000 newborns with female phenotype. Cytogenetically, the syndrome is characterized by sex chromosome monosomy $(45, X)$, which is present in $50-60 \%$ of the cases. The other cases present mosaicism, with a $45, X$ cell line accompanied by one or more other cell lines with a complete or structurally abnormal $X$ or $Y$ chromosome. The presence of $\mathrm{Y}$-chromosome material in patients with dysgenetic gonads increases the risk of gonadal tumors, especially gonadoblastoma. The greatest concern is the high risk of developing gonadoblastoma or other tumors and virilization during puberty if chromosome Y-specific sequences are present. The role of the $\mathrm{Y}$ chromosome in human oncogenesis is still controversial. Even though gonadoblastoma is a benign tumor, it can undergo transformation into invasive dysgerminoma in $60 \%$ of the cases, and also into other, malignant forms of germ cell tumors. Although some authors have questioned the high incidence of gonadoblastoma (around 30\%), the risk of developing any kind of gonadal lesion, whether tumoral or not, justifies investigation of Y-chromosome sequences by means of the polymerase chain reaction (PCR), a highly sensitive, low-cost and easy-to-perform technique. In conclusion, mosaicism of both the $\mathrm{X}$ and the $\mathrm{Y}$ chromosome is a common finding in TS, and detection of $Y$-chromosome-specific sequences in patients, regardless of their karyotype, is necessary in order to prevent the development of gonadal lesions.
\end{abstract}

\section{RESUMO}

A síndrome de Turner (ST) é uma das aneuploidias mais comuns em humanos e está presente em 1:2000 recém-nascidas com fenótipo feminino. Citogeneticamente, a síndrome é caracterizada por uma monossomia de cromossomo sexual (45,X) em 50-60\% dos casos. Os demais casos apresentam mosaicismo com uma linhagem celular 45,X acompanhada de outra(s) com o cromossomo $X$ ou $Y$ íntegros ou com alterações estruturais. A presença de material do cromossomo $\mathrm{Y}$ em pacientes com gônadas disgenéticas aumenta o risco de tumores gonadais, especialmente gonadoblastoma. A consideração mais importante diz respeito ao elevado risco de desenvolvimento de gonadoblastoma ou outros tumores e a virilização na puberdade se sequências cromossomo Y-específicas estiverem presentes. 0 papel do cromossomo $Y$ na oncogênese dos cânceres humanos ainda é controverso. Apesar de o gonadoblastoma ser um tumor benigno, ele pode transformar-se num disgerminoma invasivo em $60 \%$ dos casos e também em outras formas malignas de tumores de células germinativas. Apesar de alguns autores questionarem a alta incidência (em torno de 30\%) de gonadoblastoma, o risco do desenvolvimento de qualquer tipo de lesão gonadal, tumoral ou não, justifica a pesquisa de sequências do cromossomo Y por PCR (reação de polimerase em cadeia), técnica de alta sensibilidade, baixo custo e fácil execução. Em conclusão, o mosaicismo cromossômico tanto do X como do Y é um fato comum na ST e a detecção de sequências cromossomo Y-específicas nas portadoras, independentemente do seu cariótipo, é necessária para prevenir o desenvolvimento de lesões gonadais.
'BSC. Postgraduate Course on Cell and Molecular Biology, Centro de Extensão Universitária (CEU), São Paulo, Brazil.

"MD, PhD. Associate professor, Division of Endocrinology, Department of Medicine, Universidade Federal de São Paulo (Unifesp); and Professor of Postgraduate Course on Cell and Molecular Biology, Centro de Extensão Universitária (CEU), São Paulo, Brazil.

I'PhD. Affiliated professor, Division of Endocrinology, Department of Medicine, Universidade Federal de São Paulo (Unifesp), São Paulo, Brazil.

"MD, PhD. Postgraduate student, Division of Endocrinology, Department of Medicine, Universidade Federal de São Paulo (Unifesp), São Paulo, Brazil.

VBSC, PhD. Biomedical specialist in the Department of Medicine and postgraduate student, Division of Endocrinology, Department of Medicine, Universidade Federal de São Paulo (Unifesp); and Professor of Postgraduate Course on Cell and Molecular Biology, Centro de Extensão Universitária (CEU), São Paulo, Brazil. 


\section{INTRODUCTION}

In 1938, Henry Turner ${ }^{1}$ described a group of female adolescents with primary amenorrhea, sexual infantilism and short stature. The patients also presented cubitus valgus, webbed neck, widely spaced nipples, low posterior hairline and lymphedema of hands and feet. Four years later, Varney et al. ${ }^{2}$ and Albright et al., ${ }^{3}$ independently from each other, studied patients with clinical signs resembling those described by Turner and demonstrated that, after puberty, they presented a high level of urinary gonadotropins, thus establishing that there was an abnormality of gonadal function rather than a hypothalamic or hypophyseal deficiency. In 1944, Wilkins and Fleischmann ${ }^{4}$ performed histological analyses and observed that patients with the clinical signs described by Turner, ${ }^{1}$ Varney et $\mathrm{al}^{2}$ and Albright et al. ${ }^{3}$ probably had streak gonads, and that all those authors were studying the same syndrome: Turner's syndrome.

Turner's syndrome (TS) is one of the most common types of aneuploidy in humans, and is present in 1:2000 newborns with female phenotype. ${ }^{5,6}$ The first karyotype investigation in a patient with TS was performed in England, in 1959, by Ford et al. ${ }^{7}$ These authors were able to describe X-chromosome monosomy, i.e. the 45, X karyotype, which is the type most frequently found among patients with $\mathrm{TS}^{8}$ (Figure 1).

\section{CLINICAL CHARACTERISTICS}

Individuals with TS present extremely variable phenotypes. Despite their undifferentiated gonads, they have clearly female external and internal genitals. However, their uterus is small, since its full development depends on hormonal stimuli. The gonads are usually two fibrous streaks in which no germ cells or follicular formations, but only tissue resembling the stroma of the ovarian cortex is detected., ${ }^{9,10}$

Other signs that are found may include dysmorphic auricles with the longitudinal axis in an oblique position, eyelids with antimongoloid slanting, internal epicanthal folds, high-arched palate, retrognathism, widely spaced nipples, short sternum, cardiovascular malformations (the most common are coarctation of the aorta and ventricular septum defects), renal malformations (such as horseshoe kidneys, urethral duplication and unilateral kidney agenesis) and hypoplasia of the fourth

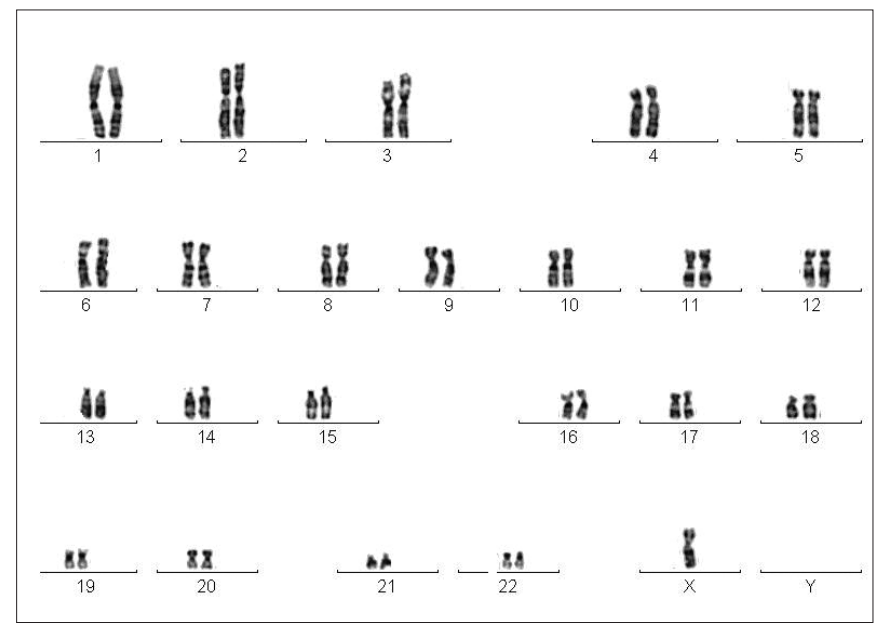

Figure 1. Turner syndrome karyotype $(45, X)$. or fifth metacarpal and metatarsal bones. Breast growth in TS patients is much slower than in normal individuals. Since women with TS present gonadal dysgenesis, the endocrine changes that are typical of puberty do not occur, and reports of primary amenorrhea are frequent ${ }^{9,10}$ (Figure 2). ${ }^{11}$

In 1997, Rao et al. ${ }^{12}$ isolated a gene named SHOX (short stature homeobox gene) that is located at Xp22 and Yp11.3, in the pseudoautosomal region of the sex chromosomes. The haploinsufficiency of this gene is believed to be responsible for the short stature and for several skeletal anomalies presented by TS patients.

TS patients present high frequencies of autoimmune diseases, particularly hypothyroidism, celiac disease and diabetes mellitus, which so far remain unexplained. ${ }^{5,10,13}$ Moreover, some authors have suggested that there is a higher risk of autoimmune diabetes among TS patients with karyotypes presenting an $\mathrm{X}$ isochromosome. ${ }^{4} \mathrm{An}$ isochromosome of the long arm of the $\mathrm{X}$ chromosome $(\mathrm{Xq})$ results from deletion of the short arm and duplication of the long arm of one of the $\mathrm{X}$ chromosomes, and this is the most common structural abnormality found in TS cases.

\section{GENETIC CHARACTERISTICS}

Cytogenetically, the Turner syndrome is characterized by sex chromosome monosomy $(45, \mathrm{X})$ in phenotypically female individuals. This karyotype is found in $50-60 \%$ of the cases. ${ }^{5,14}$ The other cases are mosaics with a $45, \mathrm{X}$ cell line accompanied by others with two or more $\mathrm{X}$ chromosomes or with structural anomalies. Such structural anomalies of the X chromosome (isochromosomes of the long arm, dicentric chromosomes, deletion of the short arm or ring chromosomes) are present in approximately $30 \%$ of the cases, in homogeneous karyotypes or in mosaics that include a 45,X cell line. Finally, around 5\% are accounted for by patients with structural abnormalities of the $\mathrm{Y}$ chromosome (isochromosomes of the long arm and dicentric chromosomes) and mosaics that include a cell line accompanied by others with at least one $\mathrm{Y}$ chromosome, whether complete or not. ${ }^{5,8}$

Data from the literature show that a second sex chromosome is necessary for the fetus to survive, and therefore virtually every liveborn

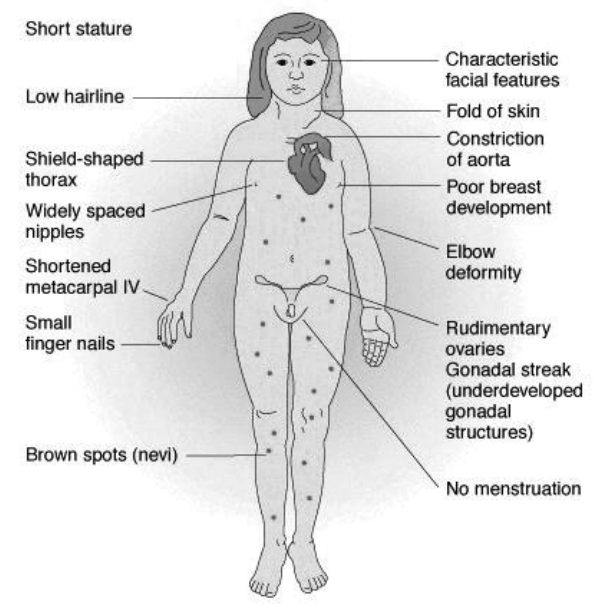

Figure 2. Clinical-phenotypic findings in Turner. ${ }^{11}$ 
45, $\mathrm{X}$ individual should present more than one cell karyotype line, thus constituting a mosaic. ${ }^{15}$ This condition would be necessary for at least some organs, during a certain period of embryogenesis. This hypothesis is based on two main points: the frequency of sex chromosome mosaicism is much higher in liveborn infants with TS than in aborted fetuses; and an estimate that approximately $99 \%$ of the embryos with a pure 45,X karyotype die in utero. ${ }^{16,17}$

Furthermore, comparison with other numerical chromosomal anomalies, such as Down syndrome or chromosome 18 trisomy, reveals that the incidence of TS does not increase with maternal age. ${ }^{18,19}$ These findings argue against meiotic nondisjunction as the main mechanism for the generation of a 45, X karyotype. Clinically, in contrast to other chromosomal syndromes, even patients with a pure 45,X karyotype present completely distinct phenotypes. Except for short stature, which seems to be a general characteristic, all other findings are inconsistent. One of the possible explanations for this fact might be undetected mosaicism, since the diagnosis is usually made by analyzing between 5 and 30 peripheral blood lymphocytes to determine the karyotype,${ }^{20}$ and the second cell line is often present as a proportion of no more than 1 to $2 \%$ of the individual's cells.

In around $99 \%$ of human conceptuses with a 45, X karyotype, natural loss occurs during the first stage of embryonic development. ${ }^{15,17}$ Only $1 \%$ of these fertilizations are successful, and they generally display TS characteristics. ${ }^{1}$ Both embryonic mortality and the characteristic TS phenotype are considered to result from monosomy of genes that are common to the $\mathrm{X}$ and $\mathrm{Y}$ chromosomes (pseudoautosomal region). ${ }^{21} \mathrm{In}$ women, it is clear that these genes are expressed both in the active and in the inactivated $\mathrm{X}$ chromosome, as a means of ensuring the proper amount of gene product. It is believed that one or more of these genes are responsible for TS. ${ }^{22,23}$

\section{DETECTION OF MOSAICISM}

The detection of mosaicism is determined mainly by four factors: the type and number of tissues analyzed; the number of cells studied; ${ }^{16}$ the sensitivity of the techniques used; and the possibility of selection, which can result in disappearance of cell lines. ${ }^{15,24}$ A small percentage of mosaicism cannot be detected by the classical cytogenetic technique, because this kind of analysis requires a large number of cells. The use of molecular techniques such as fluorescence in situ hybridization (FISH) and the polymerase chain reaction (PCR) substantially improves the detection of low-frequency cell lines and possible structural abnormalities. $^{23,25}$

Peripheral blood lymphocytes are generally the material of choice for cytogenetic analysis on patients suspected of having TS, since this tissue is easy to obtain. In routine laboratory diagnosis, the classical cytogenetic analysis is performed in thirty metaphases, which allows detection of $10 \%$ mosaicism. If the hypothesis that all patients with Turner syndrome carry mosaicism is true, it is possible that cell lines that are present in blood at frequencies below $10 \%$ go undetected by this method. ${ }^{26}$

Another issue to be considered is the analysis of different tissues, since mosaicism may not be detected in peripheral blood, but may be significant in tissue samples of different embryonic origin, for example oral mucosa. ${ }^{26-29}$

The presence of Y-chromosome material in individuals with TS can be investigated both cytogenetically and by using various molecular approaches. ${ }^{30}$ The latter presents the advantages of not needing cell cultures and requiring only a rather small amount of material. Thus, the use of molecular methods for identifying Y-chromosome-specific sequences has become an indispensable tool for detecting hidden mosaicism. ${ }^{31-34}$

Nazarenko et al. ${ }^{35}$ also observed that cytogenetic analysis may not provide precise information on the presence of chromosomal mosaicism in patients with TS. Additional analysis of cells from tissues of different embryonic origins (mesodermal lymphocytes and ectodermal oral epithelium cells, for instance) allowed greater precision in defining the cytogenetic diagnosis. FISH analysis with a probe for the $\mathrm{X}$ chromosome allowed a more accurate result, thus showing that $29 \%$ out of fifty patients with pure $\mathrm{X}$ monosomy detected by ordinary karyotyping actually presented mosaics. In addition, according to these authors, distinct chromosomal constitution was observed in different tissues from the same individual, thereby highlighting the possibility that chromosomal abnormalities or the presence of a second sex chromosome may be absent in blood but present in other tissues.

According to Mendes et al., ${ }^{36}$ mosaicism is present in $25 \%$ of TS karyotypes. Y-chromosome-specific sequences can be observed in approximately $40 \%$ of these cases. According to López et al., ${ }^{32}$ the difficulty in comparing the frequency of Y-chromosome-specific sequences or of the $\mathrm{Y}$ chromosome itself in patients with TS is due mainly to the variability in the number of patients analyzed; the frequency of mosaicism with a normal and an abnormal X chromosome; the number of cases with marker chromosomes; the molecular methodology applied in each study; and the Y-chromosome-specific sequences studied. These authors used a combination of classical cytogenetics and molecular deoxyribonucleic acid (DNA) analysis methods to study the presence of Y-chromosome-derived material in 50 patients with Turner syndrome. Their molecular results revealed that the frequency of Y-chromosomespecific sequences was $12 \%$, whereas it had previously been found to be $2 \%$, using classical cytogenetics.

Chu et al..$^{33}$ stated that PCR is more effective than cytogenetic analysis for detecting hidden mosaicism involving the $\mathrm{Y}$ chromosome, and may be even more effective using a multiple-tissue approach, thereby raising the chances of revealing mosaicism, if present.

Guedes et al. ${ }^{37}$ studied a girl who, despite her 45,X/46,X,der(Y) karyotype, displayed no signs of virilization and/or clinical features of TS, except for decreased growth speed. After prophylactic gonadectomy, in view of the risk of developing gonadoblastoma, samples from blood and gonad material were studied by means of FISH and PCR, to search for Y-chromosome-specific sequences. These analyses revealed that the Y-derived chromosome was actually a Yp isodicentric chromosome and that there was a significant difference in the distribution of the mosaicism between the two tissues studied. Although 97.5\% of the cells analyzed in peripheral blood were $46, \mathrm{X}$,idic(Yp) with duplication of the $S R Y$ gene, this did not determine any degree of male sex differentiation, since $60 \%$ of the cells analyzed in the gonadal tissue were 45 , X, thus 
suggesting that in this patient, the tissue-specific mosaicism contributed towards female sex development.

\section{Y CHROMOSOME AND RISK OF GONADAL TUMOR DEVELOPMENT}

Abnormalities in gonad organogenesis can lead to the development of gonadal tumors, ${ }^{38}$ especially in patients with dysgenetic gonads. ${ }^{39}$ Patients with disorders of sexual development are at increased risk of developing tumors originating from germ lines, also known as germcell tumors. ${ }^{40}$ Several risk factors have been identified for these kinds of germ-cell tumors, particularly those relating to gonads, including cryptorchidism and gonadal dysgenesis. ${ }^{40-42}$

The precursor lesion for dysgenetic gonad tumors is named gonadoblastoma. ${ }^{41}$ This has the potential to progress towards invasive germ-cell tumors, particularly dysgerminoma, and, less frequently, towards components of other tumors, such as embryonic carcinoma, teratoma, yolk sac tumor and choriocarcinoma. ${ }^{43}$

Gonadoblastoma is a mixed tumor of undifferentiated cells that recapitulates gonadal development ${ }^{41}$ and is able to originate dysgermino$\mathrm{ma}$ in $60 \%$ of the cases. ${ }^{44}$ Hyperandrogenism is a phenomenon commonly associated with gonadoblastoma, especially in cases of coexistence with dysgerminoma. ${ }^{44}$

There is strong evidence that gonadoblastoma results from a disorder in germ cell maturation. This model is supported by epidemiological and morphological observations, such as the presence of immunohistochemical germ cell markers (placental alkaline phosphatase) and proto-oncogenes (c-KIT). . $^{45-47}$

The genes $S R Y^{16,20,32,36,48-56}$ and $D Y Z 3^{16,32,34,48-51,53,55-57}$ are the sequences most commonly used in studies. Controversy still exists regarding which Y-chromosome markers are the most relevant. In general, the $S R Y$ gene is the sequence most used, because of its location and important role in the sex differentiation cascade. ${ }^{58}$

However, with the identification of novel genes on the Y chromosome and the so-far unconfirmed suspicion that there is a specific gene associated with the development of gonadoblastoma, other regions have been associated with the development of this tumor. ${ }^{59}$

$G B Y$ (gonadoblastoma locus on the $\mathrm{Y}$ chromosome) is a gene that is assumed to be related to the presence of tumors originating from dysgenetic gonads. This gene is probably located within a small region of the short arm of the Y chromosome, close to the centromere. ${ }^{59}$ TSPY (testis-specific protein Y-encoded) is a candidate gene for the $G B Y$ locus, which is possibly related to the development of gonadoblastoma and the involvement of a specific region of the $\mathrm{Y}$ chromosome. ${ }^{60,61}$ Hildenbrand et al. ${ }^{62}$ studied a patient with TS and a 45,X/46,X,+mar karyotype who developed unilateral gonadoblastoma. Cytogenetic and molecular studies confirmed that the marker was derived from the $\mathrm{Y}$ chromosome. These authors investigated the gonad material by immunohistochemistry for expression of the TSPY gene, and the results revealed a high level of TSPY protein expression.

Furthermore, the POU5F1 (OCT4) gene, located at 6p21.31, is expressed in pluripotent stem cells and germ cells in mice and humans. ${ }^{63-68}$
Extensive immunohistochemical screening for POU5F1 protein expression has been carried out on several types of germ cell tumors using microarrays and has shown that their immunoreactivity is only detectable in gonadoblastoma, seminoma, dysgerminoma and embryonic carcinoma cells. ${ }^{43}$

Considering that detection of Y-chromosome-specific sequences in patients with Turner syndrome is necessary in order to prevent the development of gonadoblastoma, ${ }^{69}$ clinical characteristics such as signs of hyperandrogenism should also be considered in deciding on the therapeutic approach to be adopted for such patients. This is important because the administration of growth hormone (somatotropin) to patients carrying Y-chromosome fragments may lead to the development of this neoplasm or other androgen-secreting tumors ${ }^{70}$ although this is still a controversial matter. Treatment with growth hormone is indicated for TS patients and the results have been satisfactory, but the long-term effects resulting from this treatment are still under observation. ${ }^{71}$

The $S R Y$ gene, whose major role in sex determination and differentiation has been well known ever since the first studies of Page, ${ }^{60}$ represents an intermediate link in the signaling chain that occurs during embryonic development. It serves as an activator and is also regulated by several genes (SOX-9; WT-1; SF-1, etc.). This gene is of fundamental importance in cell differentiation and, consequently, in determining the gonadal microenvironment. The interaction starts in the presence of androgens.

It has traditionally been recommended that a search for Y-chromosome fragments in TS should only be performed under two circumstances: when there are signs of virilization and/or when there is a marker chromosome not identified by classical cytogenetics. ${ }^{72,73}$ Nevertheless, when Canto et al. ${ }^{74}$ used PCR to study 107 Turner syndrome patients with a 45,X karyotype, they identified Y-chromosome material in ten $(9.3 \%)$ of them. Prophylactic gonadectomy was indicated, and two of the six patients who agreed to undergo the surgery presented gonadoblastoma, thus indicating an incidence of $33 \%$.

Similarly, Bianco et al..$^{34}$ studied different tissue samples from 20 TS patients by means of PCR and found that seven (35\%) of the 45,X patients presented Y-chromosome-specific sequences in at least one of the tissues studied. Four (14\%) of these patients underwent prophylactic gonadectomy, and bilateral gonadoblastoma was found in a 16-year-old girl. In this case, the presence of Y-chromosome sequences was not associated with virilization, thus reinforcing the idea that absence of this characteristic does not rule out the possibility of the presence of hidden Y chromosome fragments.

In addition, Bianco et al. ${ }^{55}$ investigated the presence of Y-chromosome mosaicism (SRY, TSPY and DYZE) in 87 TS patients by means of PCR, along with its association with the development of gonadal tumors and/or nontumoral androgen-producing lesions. The data revealed hidden Y-chromosome mosaicism in $18.5 \%$ of the patients. The $S R Y$ sequence was detected in all of these patients, while $4.6 \%$ of them presented the $D Y Z 3$ repeat region and $4.6 \%$ of them presented the TSPY gene. Eleven of the patients with Y-positive sequences agreed to undergo prophylactic surgery. In two cases, bilateral gonadoblastoma was found and, in another case, histopathological analysis on the gonads revealed hilus cell hyperplasia. In a further case, hilus cell hyper- 
plasia and stromal luteoma were found. These authors concluded that a systematic search for hidden Y-chromosome mosaicism, especially for the $S R Y$ gene, in Turner syndrome patients, was justified because of the possibility of preventing gonadal lesions.

\section{CONCLUSION}

The role of the $\mathrm{Y}$ chromosome in human oncogenesis is still controversial. However, identification of Y-chromosome mosaicism is clinically important because of the high risk that tumors such as gonadoblastoma or other, nontumoral androgen-producing lesions might develop in the dysgenetic gonads of patients with hidden Y-chromosome mosaicism or Y-chromosome-specific sequences. Although gonadoblastoma is a benign tumor, it can undergo transformation into invasive dysgerminoma in $60 \%$ of the cases, and can also turn into other malignant forms of germ-cell tumors. Even though some authors have questioned the high incidence of gonadoblastoma (around 30\%), the possibility that some kind of gonadal lesion might develop, whether tumoral or not, justifies investigation of Y-chromosome-specific sequences by means of PCR, which is a highly sensitive, low cost and easy-to-perform technique.

In conclusion, mosaicism of both the $\mathrm{X}$ and the $\mathrm{Y}$ chromosome is a common finding in TS, and detection of Y-chromosome-specific sequences in such patients, regardless of their karyotype, is necessary in order to prevent the development of gonadal lesions.

\section{REFERENCES}

1. Classic pages in obstetrics and gynecology by Henry H. Turner. A syndrome of infantilism, congenital webbed neck, and cubitus valgus. Endocrinology, vol. 23, pp. 566-574, 1938. Am J Obstet Gynecol. 1972;113(2):279.

2. Varney RF, Kenyon AT, Koch FC. An association of short stature, retarded sexual development and high urinary gonadotropin titers in women. The Journal of Clinical Endocrinology. 1942;2(3):137-45. Available from: http://jcem.endojournals.org/cgi/content/ abstract/2/3/137. Accessed in 2009 (Nov 24).

3. Albright F, Smith PH, Fraser R. A syndrome characterized by primary ovarian insufficiency and decreased stature: report of 11 cases, with a digression on hormonal control of axillary and pubic hair.The American Journal of the Medical Sciences. 1942;204(5):62548. Available from: http://journals.lww.com/amjmedsci/Citation/1942/11000/A_ SYNDROME_CHARACTERIZED_BY_PRIMARY_OVARIAN.1.aspX. Accessed in 2009 (Nov 24).

4. Wilkins L, Fleischmann W. Ovarian agenesis. Pathology, associated clinical symptoms and the bearing on the theories of sex differentiation. The Journal of Clinical Endocrinology. 1944;4(8):357-75. Available from: http://jcem.endojournals.org/cgi/content/ abstract/4/8/357. Accessed in 2009 (Nov 24).

5. Lippe B. Turner syndrome. Endocrinol Metab Clin North Am. 1991;20(1):121-52.

6. Gravholt $\mathrm{CH}$, Juul S, Naeraa RW, Hansen J. Prenatal and postnatal prevalence of Turner's syndrome: a registry study. BMJ. 1996;312(7022):16-21.

7. Ford CE, Jones KW, Polani PE, De Ameida JC, Briggs JH. A sex-chromosome anomaly in a case of gonadal dysgenesis (Turner's syndrome). Lancet. 1959;1(7075):711-3.

8. Beiguelman B. Citogenética humana. 1a ed. Rio de Janeiro: Guanabara Koogan; 1982.

9. Elsheikh M, Wass JA, Conway GS. Autoimmune thyroid syndrome in women with Turner's syndrome--the association with karyotype. Clin Endocrinol (0xf). 2001;55(2):223-6.

10. Gravholt $\mathrm{CH}$. Epidemiological, endocrine and metabolic features in Turner syndrome. Arq Bras Endocrinol Metabol. 2005;49(1):145-56.

11. Vogel F, Motulsky A. Human genetics: problems and approaches. $3^{\text {rd }}$ ed. London: SpringerVerlag; 1996.

12. Rao $\mathrm{E}$, Weiss $\mathrm{B}$, Fukami $\mathrm{M}$, et al. Pseudoautosomal deletions encompassing a novel homeobox gene cause growth failure in idiopathic short stature and Turner syndrome. Nat Genet. 1997;16(1):54-63.

13. Gravholt $\mathrm{CH}$. Epidemiological, endocrine and metabolic features in Turner syndrome. Eur J Endocrinol. 2004;151(6):657-87.
14. Stratakis CA, Rennert OM. Turner syndrome: molecular and cytogenetics, dysmorphology, endocrine, and other clinical manifestations and their management. The Endocrinologist. 1994;4(6):442-53. Available from: http://journals.Iww.com/theendocrinologist/ Abstract/1994/11000/Turner_Syndrome_Molecular_and_Cytogenetics,.7.aspx. Accessed in 2009 (Nov 24).

15. Held KR, Kerber S, Kaminsky E, et al. Mosaicism in 45,X Turner syndrome: does survival in early pregnancy depend on the presence of two sex chromosomes? Hum Genet. 1992;88(3):288-94.

16. Hook EB, Warburton D. The distribution of chromosomal genotypes associated with Turner's syndrome: livebirth prevalence rates and evidence for diminished fetal mortality and severity in genotypes associated with structural $X$ abnormalities or mosaicism. Hum Genet. 1983;64(1):24-7

17. Hassold T, Benham F, Leppert M. Cytogenetic and molecular analysis of sex-chromosome monosomy. Am J Hum Genet. 1988;42(4):534-41.

18. Carothers AD, Frackiewicz A, De Mey R, et al. A collaborative study of the aetiology of Turner syndrome. Ann Hum Genet. 1980;43(4):355-68.

19. Ferguson-Smith MA, Yates JR. Maternal age specific rates for chromosome aberrations and factors influencing them: report of a collaborative european study on 52965 amniocenteses. Prenat Diagn. 1984 Spring;4 Spec No:5-44.

20. Yorifuji T, Muroi J, Kawai M, Sasaki H, Momoi T, Furusho K. PCR-based detection of mosaicism in Turner syndrome patients. Hum Genet. 1997;99(1):62-5.

21. Ferguson-Smith MA. Karyotype-phenotype correlations in gonadal dysgenesis and their bearing on the pathogenesis of malformations. J Med Genet. 1965;39:142-55.

22. Burgoyne PS. Mammalian sex determination: thumbs down for zinc finger? Nature 1989;342(6252):860-2.

23. Fisher EM, Beer-Romero P, Brown LG, et al. Homologous ribosomal protein genes on the human $X$ and $Y$ chromosomes: escape from $X$ inactivation and possible implications for Turner syndrome. Cell. 1990;63(6):1205-18

24. Procter SE, Watt JL, Lloyd DJ, Duffty P. Problems of detecting mosaicism in skin. A case of trisomy 8 mosaicism illustrating the advantages of in situ tissue culture. Clin Genet. 1984;25(3):273-7.

25. Fernández R, Méndez J, Pásaro E. Turner syndrome: a study of chromosomal mosaicism. Hum Genet. 1996;98(1):29-35.

26. Quilter CR, Taylor K, Conway GS, Nathwani N, Delhanty JD. Cytogenetic and molecular investigations of $Y$ chromosome sequences and their role in Turner syndrome. Ann Hum Genet. 1998;62(Pt 2):99-106.

27. Hanson L, Bryman I, Barreñas ML, et al. Genetic analysis of mosaicism in 53 women with Turner syndrome. Hereditas. 2001;134(2):153-9.

28. Hanson L, Bryman I, Jason PO, Jakobsen AM, Hanson C. Fluorescence in situ hybridisation analysis and ovarian histology of women with Turner syndrome presenting with Y-chromosomal material: a correlation between oral epithelial cells, lymphocytes and ovarian tissue. Hereditas. 2002;137(1):1-6.

29. Premi S, Srivastava J, Panneer G, Ali S. Startling mosaicism of the Y-chromosome and tandem duplication of the SRY and DAZ genes in patients with Turner Syndrome. PLoS One. 2008;3(11):e3796

30. Nishi MY, Domenice S, Medeiros MA, Mendonca BB, Billerbeck AE. Detection of Y-specific sequences in 122 patients with Turner syndrome: nested PCR is not a reliable method. Am J Med Genet. 2002;107(4):299-305.

31. Lobaccaro JM, Medlej R, Berta P, et al. PCR analysis and sequencing of the SRY sex determining gene in four patients with bilateral congenital anorchia. Clin Endocrinol (Oxf). 1993;38(2):197-201

32. López $M$, Canto $P$, Aguinaga $M$ et al. Frequency of $Y$ chromosomal material in Mexican patients with Ullrich-Turner syndrome. Am J Med Genet. 1998;76(2):120-4.

33. Chu C. Y-chromosome mosaicism in girls with Turner's syndrome. Clin Endocrinol (Oxf). 1999;50(1):17-8

34. Bianco B, Lipay MV, Melaragno MI, Guedes AD, Verreschi IT. Detection of hidden Y mosaicism in Turner's syndrome: importance in the prevention of gonadoblastoma. J Pediatr Endocrinol Metab. 2006;19(9):1113-17.

35. Nazarenko SA, Timoshevsky VA, Sukhanova NN. High frequency of tissue-specific mosaicism in Turner syndrome patients. Clin Genet. 1999;56(1):59-65.

36. Mendes JR, Strufaldi MW, Delcelo R, et al. Y-chromosome identification by PCR and gonadal histopathology in Turner's syndrome without overt Y-mosaicism. Clin Endocrinol (Oxf). 1999;50(1):19-26.

37. Guedes AD, Bianco B, Lipay MV, Brunoni D, de Lourdes Chauffaille M, Verreschi IT. Determination of the sexual phenotype in a child with $45, \mathrm{X} / 46, \mathrm{X}, \mathrm{Idic}(\mathrm{Yp})$ mosaicism: importance of the relative proportion of the $45, X$ line in gonadal tissue. Am J Med Genet A. 2006;140A(17):1871-5.

38. Verp MS, Simpson JL. Abnormal sexual differentiation and neoplasia. Cancer Genet Cytogenet. 1987;25(2):191-218. 
39. Lipay MV, Bianco B, Verreschi IT. Disgenesias gonadais e tumores: aspectos genéticos e clínicos [Gonadal dysgenesis and tumors: genetic and clinical features]. Arq Bras Endocrinol Metabol. 2005;49(1):60-70.

40. Skakkebaek NE. Testicular dysgenesis syndrome. Horm Res. 2003;60 Suppl 3:49

41. Scully RE. Gonadoblastoma. A review of 74 cases. Cancer. 1970;25(6):1340-56.

42. Skakkebaek NE, Holm M, Hoei-Hansen C, Jørgensen N, Rajpert-De Meyts E. Association between testicular dysgenesis syndrome (TDS) and testicular neoplasia: evidence from 20 adult patients with signs of maldevelopment of the testis. APMIS. 2003;111(1):1-9; discussion 9-11.

43. Looijenga LH, Stoop H, de Leeuw HP, et al. POU5F1 (OCT3/4) identifies cells with pluripotent potential in human germ cell tumors. Cancer Res. 2003;63(9):2244-50.

44. Saenger P. Clinical review 48: The current status of diagnosis and therapeutic intervention in Turner's syndrome. J Clin Endocrinol Metab. 1993;77(2):297-301.

45. Hustin J, Gillerot $Y$, Collette J, Franchimont P. Placental alkaline phosphatase in developing normal and abnormal gonads and in germ-cell tumours. Virchows Arch A Pathol Anat Histopathol. 1990;417(1):67-72

46. Jørgensen N, Müller J, Jaubert F, Clausen OP, Skakkebaek NE. Heterogeneity of gonadoblastoma germ cells: similarities with immature germ cells, spermatogonia and testicular carcinoma in situ cells. Histopathology. 1997;30(2):177-86

47. Słowikowska-Hilczer J, Walczak-Jedrzejowska R, Kula K. Immunohistochemical diagnosis of preinvasive germ cell cancer of the testis. Folia Histochem Cytobiol. 2001;39(2):67-72.

48. Kocova M, Siegel SF, Wenger SL, Lee PA, Trucco M. Detection of $Y$ chromosome sequences in Turner's syndrome by Southern blot analysis of amplified DNA. Lancet. 1993;342(8864):140-3.

49. Coto E, Toral JF, Menéndez MJ, et al. PCR-based study of the presence of Y-chromosome sequences in patients with Ullrich-Turner syndrome. Am J Med Genet. 1995;57(3):393-6.

50. Mancilla EE, Poggi H, Repetto G, et al. Y chromosome sequences in Turner's syndrome: association with virilization and gonadoblastoma. J Pediatr Endocrinol Metab. 2003;16(8):1157-63.

51. Binder G, Koch A, Wajs E, Ranke MB. Nested polymerase chain reaction study of 53 cases with Turner's syndrome: is cytogenetically undetected Y mosaicism common? J Clin Endocrinol Metab. 1995;80(12):3532-6.

52. Osipova GR, Karmanov ME, Kozlova SI, Evgrafov OV. PCR detection of Y-specific sequences in patients with Ullrich-Turner syndrome: clinical implications and limitations. Am J Med Genet. 1998;76(4):283-7.

53. Damiani D, Guedes DR, Fellous M, et al. Ullrich-Turner syndrome: relevance of searching for Y chromosome fragments. J Pediatr Endocrinol Metab. 1999;12(6):827-31.

54. Gravholt CH, Fedder J, Naeraa RW, Müller J. Occurrence of gonadoblastoma in females with Turner syndrome and Y chromosome material: a population study. J Clin Endocrinol Metab. 2000;85(9):3199-202.

55. Bianco B, Lipay M, Guedes A, Oliveira K, Verreschi IT. SRY gene increases the risk of developing gonadoblastoma and/or nontumoral gonadal lesions in Turner syndrome. Int J Gynecol Pathol. 2009;28(2):197-202.

56. Araujo C, Galera MF, Galera BB, Silvestre FG, Medeiros SF. Molecular identification of chromosomeY sequences in Brazilian patients with Turner syndrome. Gynecol Endocrinol. 2008;24(12):713-7.

57. Semerci CN, Satiroglu-Tufan NL, Turan S, et al. Detection of $Y$ chromosomal material in patients with a 45,X karyotype by PCR method. Tohoku J Exp Med. 2007;211(3):243-9.

58. Harley VR, Clarkson MJ, Argentaro A. The molecular action and regulation of the testis-determining factors, SRY (sex-determining region on the Y chromosome) and SOX9 [SRY-related high-mobility group (HMG) box 9]. Endocr Rev. 2003;24(4):466-87.

59. Tsuchiya K, Reijo R, Page DC, Disteche CM. Gonadoblastoma: molecular definition of the susceptibility region on the Y chromosome. Am J Hum Genet. 1995;57(6):1400-7.

60. Page DC. Hypothesis: a Y-chromosomal gene causes gonadoblastoma in dysgenetic gonads. Development. 1987;101 Suppl:151-5.
61. Salo P, Kääriäinen H, Petrovic V, Peltomäki P, Page DC, de la Chapelle A. Molecular mapping of the putative gonadoblastoma locus on the $Y$ chromosome. Genes Chromosomes Cancer. 1995;14(3):210-4

62. Hildenbrand R, Schröder W, Brude E, et al. Detection of TSPY protein in a unilateral microscopic gonadoblastoma of a Turner mosaic patient with a Y-derived marker chromosome. Pathol. 1999;189(4):623-6.

63. Schöler HR, Dressler GR, Balling R, Rohdewohld H, Gruss P. Oct-4: a germline-specific transcription factor mapping to the mouse t-complex. EMBO J. 1990;9(7):2185-95.

64. Okamoto K, Okazawa H, Okuda A, Sakai M, Muramatsu M, Hamada H. A novel octamer binding transcription factor is differentially expressed in mouse embryonic cells. Cell. 1990;60(3):461-72.

65. Rosner MH, Vigano MA, Ozato K, et al. A POU-domain transcription factor in early stem cells and germ cells of the mammalian embryo. Nature. 1990;345(6277):686-92.

66. Pera MF, Herszfeld D. Differentiation of human pluripotent teratocarcinoma stem cells induced by bone morphogenetic protein-2. Reprod Fertil Dev. 1998;10(7-8):551-5.

67. Goto T, Adjaye J, Rodeck $\mathrm{CH}$, Monk M. Identification of genes expressed in human primordia germ cells at the time of entry of the female germ line into meiosis. Mol Hum Reprod. 1999;5(9):851-60

68. Hansis C, Grifo JA, Krey LC. Oct-4 expression in inner cell mass and trophectoderm of human blastocysts. Mol Hum Reprod. 2000;6(11):999-1004

69. Ramos ES. Turner syndrome: counseling prior to oocyte donation. Sao Paulo Med J. 2007;125(2):112-4.

70. Rosen GF, Kaplan B, Lobo RA. Menstrual function and hirsutism in patients with gonadal dysgenesis. Obstet Gynecol. 1988;71(5):677-80.

71. Cabanas P, García-Caballero T, Barreiro J, et al. Papillary thyroid carcinoma after recombinant GH therapy for Turner syndrome. Eur J Endocrinol. 2005;153(4):499-502.

72. Saenger P, Wikland KA, Conway GS, et al. Recommendations for the diagnosis and management of Turner syndrome. J Clin Endocrinol Metab. 2001;86(7):3061-9.

73. Frías JL, Davenport ML; Committee on Genetics and Section on Endocrinology.. Health supervision for children with Turner syndrome. Pediatrics. 2003;111(3):692-702.

74. Canto P, Kofman-Alfaro S, Jiménez AL, et al. Gonadoblastoma in Turner syndrome patients with nonmosaic 45,X karyotype and $Y$ chromosome sequences. Cancer Genet Cytogenet. 2004;150(1):70-2

Acknowledgements: Fundação de Amparo à Pesquisa do Estado de São Paulo (Fapesp) Sources of funding: Fundação de Amparo à Pesquisa do Estado de São Paulo (Fapesp grant number 2007/01241-0)

Conflict of interest: Not declared

Date of first submission: February 6, 2009

Last received: July 31, 2009

Accepted: December 8, 2009

Address for correspondence:

Bianca Bianco

Disciplina de Endocrinologia

Universidade Federal de São Paulo (Unifesp)

Rua Pedro de Toledo, 781 - 13ํandar

Vila Clementino - São Paulo (SP) - Brasil

CEP 04039-032

Tel./Fax. (+55 11) 5574-6502

E-mail. bianca.bianco@hotmail.com 